\title{
Interfaces
}

\section{Allure without Allusion: Quoting a Virgilian Epitaph in a 9/11 Memorial}

Aaron Seider

\section{(2) OpenEdition}

1 Journals

\section{Electronic version}

URL: http://journals.openedition.org/interfaces/321

DOI: $10.4000 /$ interfaces.321

ISSN: 2647-6754

\section{Publisher:}

Université de Bourgogne, Université de Paris, College of the Holy Cross

\section{Printed version}

Date of publication: 1 January 2017

Number of pages: 173-194

ISSN: 1164-6225

\section{Electronic reference}

Aaron Seider, "Allure without Allusion: Quoting a Virgilian Epitaph in a 9/11 Memorial", Interfaces

[Online], 38 | 2017, Online since 13 June 2018, connection on 07 January 2021. URL: http:// journals.openedition.org/interfaces/321 ; DOI: https://doi.org/10.4000/interfaces.321

Les contenus de la revue Interfaces sont mis à disposition selon les termes de la Licence Creative Commons Attribution 4.0 International. 


\title{
ALLURE WITHOUT ALLUSION: QUOTING A VIRGILIAN EPITAPH IN A 9/11 MEMORIAL
}

\author{
Aaron Seider
}

When the National September 11 Memorial \& Museum opened in 2014, a quotation from the Aeneid thrust its 2,000-year-old author into a contemporary debate about honor and remembrance. Emblazoned on the central wall of Memorial Hall, the sentence "No day shall erase you from the memory of time," attributed simply to Virgil, stood high above the museum's visitors. This elegant translation of the Latin phrase nulla dies umquam memori vos eximet aevo, ${ }^{1}$ line 447 in the ninth book of Virgil's epic poem the Aeneid, sparked a series of conversations in newspapers and magazines about the appropriateness of transferring a Virgilian epitaph for two mythological soldiers to the victims of the $9 / 11$ attacks. While these reactions focused on the challenges posed by the relationship between ancient and modern contexts, they left unexplored consequential issues of appropriation and commemoration that reorient the interpretive possibilities of the contexts of Virgil's words and subtend the dynamics of nearly every act of quotation.

In this article I explore how this single act of appropriation compels the consideration and reconsideration of these words' relationships with their ancient and modern contexts. While some aspects of the verse's original setting complicate its memorializing function in the Memorial Museum, a fuller exploration of its ancient and modern contexts reveals the power of quotation as a form of appropriation that demands a new interpretation. More specifically, I argue that this quotation in the Memorial Museum exemplifies the tension between the allure of antiquity and the impossibility of controlling its meaning, as Virgil's promise of eternal remembrance occasions larger concerns about time and memory that leave the signification of its words unstable and erase borders between texts and audiences. At the same time, though, as this interaction between different contexts destabilizes the words' commemorative force, the friction produced by that interaction offers new insight into other commemorative appropriations in the Memorial Museum and in Virgil's Aeneid. For the Memorial Museum, this engagement with the Aeneid illuminates a dialogue between the universal and the unique, while these words' placement within the Memorial Museum highlights the futility of trying to control commemoration within the Aeneid.

$1 \quad$ All Latin quotations come from the Mynors edition 
Beginning with its use in the Memorial Museum, I consider the interaction between this quotation and its various contexts, with a particular focus on how appropriated words and objects generate a new and, ultimately uncontrollable, interpretive energy. The article's first section explores how in the Memorial Museum this Roman verse seeks to enshrine the victims of 9/11 within a permanent commemoration dependent on its viewers. Yet, as I show in the article's second section, an initial investigation of these words' usage in Book 9 of the Aeneid reveals how their original context prompts questions about the focus, agency, and purpose of this modern appropriation. Such friction, though, is inevitable to any act of quotation and, in this case, any discomfort, given that it depends on a thorough knowledge of the verse's original context, remains unnoticed by the museum's great majority of visitors. Rather than focusing solely on how the quotation's original context may undermine its current purpose, I move in the article's third section to consider how the engagement between the Aeneid and the Memorial Museum offers insight into the memorializing efforts of both the modern museum and Virgil's ancient epic. For the Memorial Museum this interaction between ancient and modern frames the museum's own exploration of the commemorative tensions between the universal and the unique, while for the Aeneid this friction with a modern institution reveals its own ambivalence about the ability of any individual to control the outcome of a commemorative act.

Lastly, in a coda to the article, I further explore the tension between the allure of quotation and the impossibility of controlling it by considering a recent exhibition at the Capitoline Museum in Rome. Here, in a series of rooms that survey the history of the Capitoline Hill, the Capitoline Museum offers two quotations on opposing walls: one presents the National September 11 Memorial Museum's quotation of Virgil along with an Italian translation, while the other offers three lines of the original Latin context and an Italian translation of these verses. Pointedly framing itself as an echo both of the Aeneid and the National September 11 Memorial Museum, these Capitoline Museum quotations showcase the destabilizing yet energetic force of appropriation, as they reclaim Virgil's words for their proper Roman context and underscore the necessary symbiosis between destruction and commemoration.

\section{The Immediate Context: A Stately Selection}

Considered without any other information than can be gleaned from its immediate context, the Memorial Museum's selection from a poet of antiquity offers a solemn and comforting promise of eternal commemoration to the victims of 9/11. Memorial Hall, an austere and sparsely furnished space within the Memorial Museum, showcases the poet's words on one of its walls. As can be seen 
from Image 1, the statement "NO DAY SHALL ERASE YOU FROM THE MEMORY OF TIME" is attributed to "Virgil" and set within a large array of blue sheets of paper. It promises nothing less than everlasting remembrance. The subject of the sentence, "no day," is juxtaposed with the evocative phrase "the memory of time," a vow of continuous and infinite commemoration. Set between these two temporal poles is the sentence's object, "you," an apostrophe of those who perished in the attacks. As Jonathan Culler notes about apostrophe in general (68, emphases original), "The narrator places [what is apostrophized] beyond the movement of temporality ... Apostrophe resists narrative because its now is not a moment in a temporal sequence but a now of discourse, of writing ...." In Memorial Hall, the apostrophized victims of $9 / 11$ are moved into a present that is renewed with each reader. The main verb of the sentence, "erase," made negative by "no," promises that the $9 / 11$ victims have already been recorded in memory, and the futurity of this statement, expressed by the august "shall" rather than the mundane "will," states their commemoration will never cease.

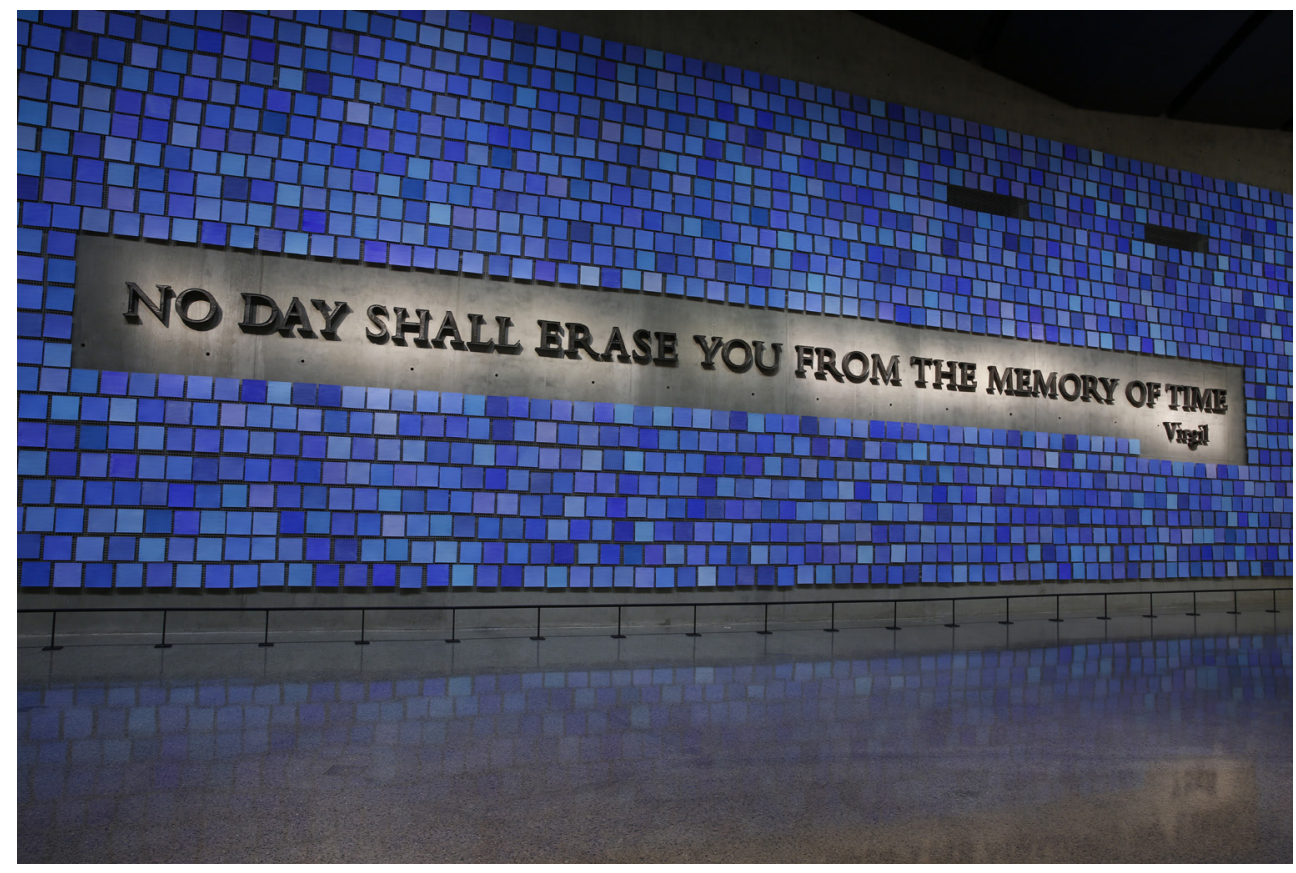

Fig. 1. Memorial Hall, National September 11 Memorial \& Museum at the World Trade Center Foundation, Inc. Photograph by Jin Lee. http://www.911memorial. org/sites/all/files/blog/ images/memhall.JPG 
The attribution of these words to Virgil amplifies this effect. Positioned directly below "TIME," "Virgil" evokes ancient Rome as a mark of authority for the quotation's truth. Additionally, this attribution signals that Virgil and his words have been remembered across the centuries, a longevity that stands as a testament to memory's power. In other words, the fact that Virgil and his words are not forgotten subtly underscores the permanence of this American cultural institution. These nebulous associations with Virgil and Rome, absent any specific link with the author's writing or Rome's history, grant the quotation a timeless significance unavailable to a contemporary author's words.

The words' aesthetic qualities and immediate surroundings add to the solemnity and permanence they promise. The 43 letters that comprise the quotation and its attribution are forged from steel and anchored in concrete. Both the words and this wall testify to the human ability to craft lasting physical constructions, with the combination of steel and concrete underlining the permanence of the memory promised by these words. The singular colors of the letters and concrete contrast with the shimmering array of watercolor drawings, each a slightly different shade of blue. Attached to a wire mesh protruding from the wall, these sheets of paper create an evocative contrast between the concrete and letters' solid colors and lasting physical nature and the paper's various colors and fragile physical presence. This juxtaposition enriches the meaning of Virgil's verse in several different ways. The permanence of the quotation's material testifies to the ability of memory to anchor different, yet related, recollections of a variety of individuals and events, while the variety of the papers and their ephemeral physical presence communicate how the details of any memory may evolve and decay. The words' material and setting promise the permanence of memory. Even as the days unfold and memories themselves change, this central cultural institution moves beyond the transitory and variable nature of an individual memory to a more permanent memorial.

\section{Discordant Notes: Modern and Ancient Contexts}

Further exploration of the quotation's contexts reveals how, while its immediate surroundings in the Memorial Museum amplify its promise of remembering the victims of 9/11, its Virgilian origins 
destabilize the identity of those who are to be commemorated. ${ }^{2}$ Before considering Virgil's epic in greater detail, it is useful to consider how the words' letters and their surroundings evoke a commitment to remembering the moment of the attacks as well as the efforts to rebuild afterwards.

This commitment begins with the metal of the letters themselves. The artist Tom Joyce forged the letters out of steel salvaged from the World Trade Center. This material commemorates not just the 9/11 attack, but also the dedication to rebuilding after it. The commitment to rebuild becomes a commitment to remember, and the entire process promises that long-standing and meaningful memories can be born from tragedy.

The surrounding artwork further emphasizes the words' promise of commemoration, as it emblematizes the different memories that members of a community may hold of a single moment. Titled "Trying to Remember the Color of the Sky on That September Morning," this creation by Spencer Finch consists of 2,983 squares of paper, all painted various shades of blue. The number of squares corresponds to the number of those killed in the 1993 and 2001 attacks on the World Trade Center, while the various shades and blendings of blues reach back toward the particular appearance of the New York City sky on September 11, 2001. In an article in The New York Times, Finch spoke about the connection between his creation and memory: "It had to be about that human quality of remembering, how it's so fuzzy in some ways, and in other ways it's so perfectly clear." 3 While the verse this artwork encircles promises eternal remembrance, the artwork itself emphasizes how the same event may be remembered in unique ways. The variations between the 2,983 squares of paper testify to the variety of memory, even as they illustrate how that variety stays within a certain range. For a visitor to Memorial Hall, it is possible to extrapolate from these efforts to remember the sky to the attempts

2 Soon after it became known that the National September 11 Memorial Museum was going to include this quotation from Virgil, writers and scholars began to question this choice in various media outlets, and in this section of the article I write about many of the ideas that these authors have already raised. The earliest voice to raise some of these issues was Caroline Alexander in an April 2011 article, when the Memorial Museum was still just being planned, and they were mentioned by Mario Erasmo in his 2012 book (p. 138). Three years later, just a few weeks before the Memorial Museum's May 2014 opening, David W. Dunlap (2014a) revisited many of these questions in a longer and more detailed article which included quotations from several scholars, and was itself accompanied by another piece (Dunlap 2014b) that presented the thoughts of classicists Helen Morales, Llewelyn Morgan, and Shadi Bartsch-Zimmer. Also, in the weeks just before the Memorial Museum opened, the classicist J. C. McKeown published a blog post considering the tension between this Virgilian verse and its original context in light of other uses of quotations from classical sources in similar memorials.

3 Kennedy 2014, C1. 
to remember the victims. Just as people might remember the sky differently, so may they remember the victims in different ways. These details about the construction of the quotation's letters and the artwork surrounding it grant more complexity to the meaning of the quotation itself, yet they do so in a way that does not threaten its central focus on commemorating the victims of 9/11. Rather, Finch's watercolors and Joyce's letters supplement the promise of Virgil's words of everlasting remembrance for the victims of $9 / 11$ by evoking ideas of resilience and recovery, individuality and community, and evanescence and timelessness.

While the quotation's surroundings within the Memorial Museum bolster its impact, its Virgilian context is jarring. The English words on the wall of Memorial Hall are a translation of a verse from Book 9 of the Aeneid and recall one of antiquity's most profound and unsettling works. Brought to a state of near-completion by Virgil before his death in 19 BCE, the Aeneid weaves together myth and history in its story of Aeneas' quest to found a city that will eventually lead to Rome. In its 12 books, containing a total of some 10,000 lines of dactylic hexameter, Virgil tells how Aeneas, the legendary ancestor of the Romans, sets out to found a new city after his home, Troy, is captured by the Greeks. Books 1-6 narrate the Trojans' voyages around the Mediterranean, as a variety of challenges plague Aeneas and his followers in their search for a home. Aeneas lands in Italy near the epic's midpoint, and Books 7-12 depict the Trojans' struggles to survive in this land, as they try to forge alliances, ward off enemies, and secure space for their city. Among its many themes, the Aeneid considers the tensions between empire and sacrifice, trauma and memory, and freedom and fate, without offering any straightforward resolutions. In the moments of determined struggle and tragic glory that make up its whole, the epic often distils Aeneas' uniquely Roman story into moments that transcend their temporal and cultural boundaries. In other words, Virgil's narration of Aeneas' story is an understandable target for quotation.

The quotation chosen by the Memorial Museum comes from a lengthy episode in Book 9 that focuses on the exploits of two Trojan soldiers, and its details bring considerable discomfort to its modern setting. With Aeneas away trying to secure an alliance with a neighboring city, a band of Latins surround the Trojans' camp. Two Trojan soldiers and lovers, Nisus and Euryalus, take this opportunity to prove their worth by volunteering to bring a message to Aeneas for help. Having slipped past the blockade in the middle of the night, the pair enters the camps of the Latins, where soldiers lie overcome by drunken sleep. Nisus and Euryalus' slaughter of their foes is thorough, and they stop only when they realize that morning will soon be upon them. 
Right before they leave, Euryalus, the younger of the pair, cannot restrain himself from plundering the armor of a dead foe, and he exits the camp with a new helmet on his head. As Nisus and Euryalus continue to Aeneas, the moonlight glints off of Euryalus' plundered helmet and a returning enemy patrol surrounds him. Realizing that he alone has escaped, Nisus returns to see Euryalus encircled by the Latins. In an attempt to save his lover, Nisus kills two of the Latins with spears, but these enemies, unable to locate Nisus, prepare to kill Euryalus instead. Nisus rushes the group with his sword, but he is too late to save Euryalus and succeeds only in slaying his lover's killer before being slaughtered himself. Virgil apostrophizes the pair directly after he finishes describing their death, and the words in Memorial Hall are a translation of one of this apostrophe's four verses, printed in bold below:

fortunati ambo! si quid mea carmina possunt, nulla dies umquam memori vos eximet aevo, dum domus Aeneae Capitoli immobile saxum accolet imperiumque pater Romanus habebit.

-Virgil, Aeneid 9.446-449

Fortunate pair! If my songs have any power, no day shall erase you from the memory of time, not while Aeneas' house stands on the Capitoline's immovable rock and the Roman father holds sway. ${ }^{4}$

As the flurry of popular articles and scholarly reactions responding to the Memorial Museum's selection points out, ${ }^{5}$ this verse's context raises several disturbing questions. Perhaps the most blatant incongruity between the quotation's modern and ancient settings lies in "you." While in the Memorial Museum "you" must be the civilian victims of the 9/11 attacks, in the Aeneid "you" are two bloodthirsty soldiers who have just slaughtered a sizeable number of their sleeping foes. Furthermore, Nisus and Euryalus are an invading force whose actions are motivated by both a desire for glory and love for each other; for the 9/11 victims, neither motivation is relevant. Perhaps most disturbingly, Nisus engages in a suicide mission when he decides to attack the enemies who surround Euryalus, an element of his death that renders him all too similar to the $9 / 11$ terrorists.

The specific claims of Virgil's apostrophe are similarly jarring. Its opening words focus on Nisus and Euryalus' shared good fortune. The exclamation "Fortunate pair!" (Fortunati ambo! Virgil, Aeneid

4 Except for the translation of the verse quoted by the Memorial Museum, all translations in this article are my own.

Alexander 2011; Dunlap 2014a; Dunlap 2014b; McKeown 2014 
9.446) may allude to the Greco-Roman notion of a beautiful death, where a young man who dies in battle at the height of his physical power gains eternal glory through commemoration. ${ }^{6}$ While the notion of facing a terrible situation together may apply to some of the victims of $9 / 11$, the claim that the $9 / 11$ victims are in any way fortunate is beyond the pale. The cultural specificity of Virgil's commemoration likewise undermines the quotation's meaning. His promise of eternal memory depends on three factors: the power of the narrator's song, the presence of Aeneas' house on the Capitoline, and the sovereignty of a Roman ruler. While Virgil's song may still have a small audience today, these three conditions can no longer be considered fulfilled. This adds two more levels of discomfort to the Memorial Museum's quotation. Firstly, if the Roman cultural institutions on which Virgil staked his song's power have disappeared, their loss implies that the same evanescence could plague their American counterparts. Secondly, with the conditions specified as necessary for commemoration no longer met, the promise of everlasting memorialization for Nisus and Euryalus is undermined, a destabilization which raises the same possibility for the victims of $9 / 11$.

These details from the quotation's ancient context are troubling, but the Memorial Museum likely decided that the allure of antiquity, with its promise of a solemn and serious eternity, outweighed the chance that visitors would be familiar with, let alone upset by, the verse's ancient context. As Llewelyn Morgan, a lecturer in Classical Languages and Literature at Oxford University, remarked in an interview in The New York Times, "Ninety-nine-point-nine percent of people won't read [Virgil's words] in context, and there's no reason why they should, but they might respond to the rhetorical move of citing an ancient author, the significance and timelessness of the sentiment that implies." Indeed, in the same article Alice M. Greenwald, the director of the Memorial Museum, confirmed the museum's intention to capitalize on the verse's ancient aura without drawing attention to its specific context: "The quote speaks to the indelibility of our memories ... In selecting this quote, our focus was not on the specific narrative of the classic story nor its characters. What resonated with us, and with everyone who reviewed its use in the context of the museum, was the reference to a single day not being able to erase the memory of those we love." In fact, after hearing the questions raised about the selection of this quotation, the Memorial Museum moved to shift its selection further away from the Aeneid's specific story and characters by changing its attribution from "Virgil, Aeneid" to "Virgil." With the title of the epic absent, this quotation stands as the personal belief of an ancient Roman poet, unencumbered by any associations with Nisus and Euryalus' deaths.

6 Vernant 1982.

7 Quoted in Dunlap 2014b.

8 Quoted in Dunlap 2014a.

9 Dunlap 2014a reports this detail. 
Even as the Memorial Museum positions this quotation at a greater distance from its original context in an effort to minimize any dissonance, an example of another Virgilian quotation suggests that it may be impossible to avoid any such tension when engaging with a text as polysemous as the Aeneid. From this perspective, the dissonance created by the Memorial Museum's selection, while it may be troublesome, is an integral aspect of invoking Virgil's epic, and, as I will argue later, if we are to consider how an examination of the ancient context may reveal aspects of discord in a quotation's modern use, we should also consider how this engagement with the Aeneid may enrich both the quotation's ancient and modern contexts.

A similar selection from the Aeneid appears on the membership certificate of the American Antiquarian Society, where once again an appeal to antiquity is designed to enhance a modern institution's prestige. Isaiah Thomas, who founded the American Antiquarian Society in 1812, commissioned a membership certificate for the society in 1819; and, as Image 2 shows, along with language testifying to the individual's membership in the American Antiquarian Society, this certificate features a picture of Christopher Columbus' storm-strewn ship with captions in both Latin and English. The English text describes what is happening in the picture it accompanies: "He (Columbus) wrote on parchment an account of his discoveries, wrapped it in a piece of oiled cloth \& enclosed it in a cake of wax, which he put in a tight cask, and threw into the sea. (Belknap.)"10 The three Latin words "OLIM MEMINISSE JUVABIT" are taken from Book 1 of the Aeneid and mean "One day it will be pleasing to remember." The lack of an English translation shows Thomas' expectation that his members will have the necessary background both to understand the Latin on their own and to consider this depiction of Columbus in light of these words' Virgilian context. A glance at that context explains why Thomas wished his members to make this connection: these words are part of Aeneas' attempt to rally his men after their companions perish in a sea storm. As Aeneas stands on the beach with the remnants of his fleet, he tells the Trojans that they have survived worse things in the past and, with a better future promised, they may remember these troubles one day with pleasure. The connections are clear. Columbus, like Aeneas, embarks on a difficult, but fated, journey to a new world, and Columbus, like Aeneas, rallies his men with the idea that they will one day remember their exploits with pleasure. For the member who possesses the American Antiquarian Society certificate, much like Virgil's original

10 As Tom Knoles, the Marcus A. McCorison Librarian at the American Antiquarian Society, writes in a brief, unpublished pamphlet on the history of the diploma, dated 2015, Abner Reed of Hartford, Connecticut engraved the plate, and the quotation is from American Biography, a 1794 book by Jeremy Belknap. An 1893 "Report of the Librarian" by Edmund M. Barton for the American Antiquarian Society also discusses on pp. 349-351 the details of the certificate in light of the society's work for the World's Columbian Exposition of that year. 
Roman readers, that day has arrived: just as Aeneas was successful in his quest and the Romans may now look back with pleasure at the Aeneid's depiction of the tribulations their ancestors survived, so may the members in Thomas' society look back and remember the challenging trials of their nation's beginnings, which they and the American Antiquarian Society now strive to record.

Yet, even in this instance, where Isaiah Thomas designed a certificate to direct his educated audience back to Book 1 of the Aeneid, a deeper examination of these words' ancient setting undercuts their rhetorical purpose on the membership certificate. To begin with, Thomas leaves out the three words which begin this sentiment in the Aeneid: forsan et haec. These words complete the Latin sentence forsan et haec olim meminisse iuvabit which, translated into English, reads "Perhaps one day

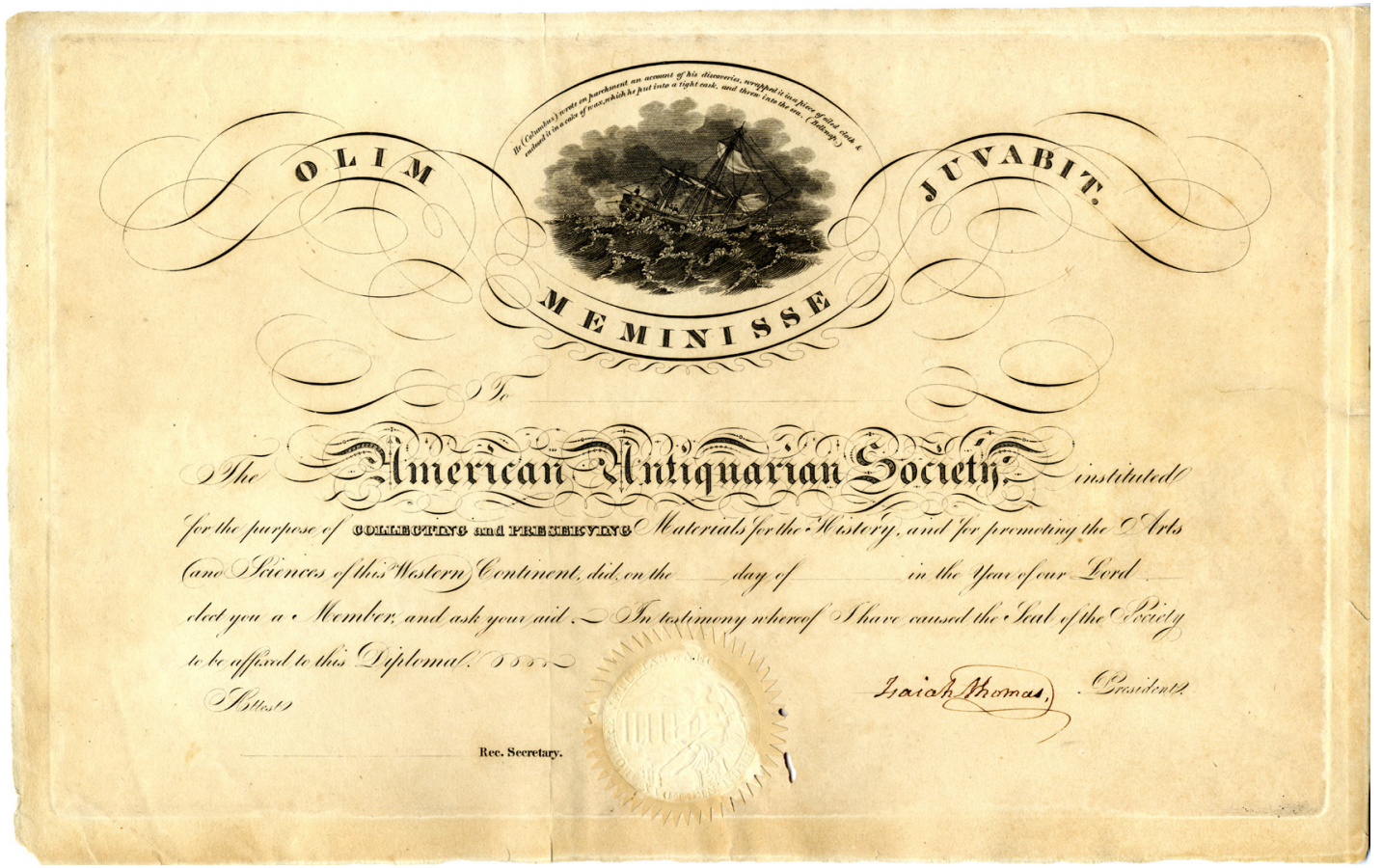

Fig. 2. Membership Certificate of American Antiquarian Society. Courtesy American Antiquarian Society. 
it will be pleasing to remember even these things" (Virgil, Aeneid 1.203). While the excision of "these" (haec) has no impact on the phrase's tenor, the same cannot be said for forsan and et. In the Virgilian verse "perhaps" (forsan) and "even" (et) undermine the certainty of Aeneas' claim, a doubt Thomas banishes. Another aspect of the original context destabilizes the certificate's claims further. As soon as Aeneas finishes speaking to his men, Virgil reveals that the Trojan does not actually believe what he just said: "Aeneas says such things in speech and yet troubled with great worries he makes a pretense of hope on his face and presses his pain deep into his heart" (talia voce refert curisque ingentibus aeger / spem vultu simulat, premit altum corde dolorem, Virgil, Aeneid 1.208-9). Furthermore, just as Aeneas doubts his own claim, the epic's larger context raises questions about these potential memories. Aeneas tells his men that they will look back on these events with pleasure since they will have survived them as a community. Yet, will this same pleasure in remembering painful events be shared by the indigenous Italians about to be displaced by the Trojans or fall under their rule? Just as the qualifiers "perhaps" and "even" undercut the certainty of the certificate's promise, these questions about the fate of those harmed by the Trojans could prompt thoughts about the Native Americans, as Columbus' arrival signifies the start of a period of displacement and suffering.

\section{Tensions That Enrich: Inevitable Complications}

In the case of the American Antiquarian Society's membership certificate, even as Thomas selects a quotation with the aim of directing his audience back to a specific section of the Aeneid, that context has the potential to undermine its present use. Indeed, the same complexity and depth that makes the Aeneid an inviting target for quotation also ensures that any such appropriation raises the possibility of tension between the original context and new context. Given this dynamic, this penultimate section of the article explores the possible ways this friction may actually enrich the quotation's ancient and modern contexts. Indeed, even as this tension between ancient and modern may prove disconcerting, it sheds light on the complexities of the promises of commemoration made by the Memorial Museum and Virgil's Roman epic. For the Memorial Museum, this tension with Virgil's poem reveals how its acts of appropriation present themselves as memorials that look simultaneously toward the universal and the unique. For the Aeneid, it illuminates how the attempt to control memory is a necessary human impulse, but one that is futile and fraught with danger.

For the Memorial Museum, this friction with the Aeneid raises questions about the interplay between the universal and the unique in the twin reflecting pools outside its entrance and in Foundation 
Hall, an interior room displaying a variety of commemorative artifacts. Both spaces reflect the conflict inherent in the Memorial Museum's double name. As both a memorial and a museum, this institution has a dual mission: to record the events of September 11, 2001 and to honor the memory of that day's victims. These aims lead to the spare, almost factual, presentation of verbal and material artifacts in an attempt to hallow these acts of commemoration themselves, and the interplay in Virgil's apostrophe between the everlasting commemoration he promises and the unique individuals who will be honored by it illustrates the Memorial Museum's work to situate specific individuals within an eternal structure.

The reflecting pools outside the Memorial Museum create aesthetic sensations linked with ideas of permanence and universality even as they set individual people within this larger context, in much the same way that Virgil's quotation promises the infinite permanence of a memory of a unique individual. The twin pools, each with water cascading down its sides, dominate the approach to the Memorial Museum. Titled "Reflecting Absence" and designed by Michael Arad, they are set within the footprints of the North and South World Trade Towers and surrounded by bronze panels inscribed with the names of those killed in the 1993 and 2001 attacks (Image 3). The water within the pools constantly moves but changes in neither its appearance nor sound, a combination that situates this space beyond human temporality. This sense of the infinite contrasts with the individual names that surround the pools (Image 4). The 2,983 names of those killed in the two attacks on the World Trade Center encircle the reflecting pools, with the names loosely organized according to personal connections. ${ }^{11}$ As Maya Lin, the designer of the Vietnam Veterans Memorial notes, the inscription of a name offers "a way to bring back everything someone could remember about a person." Each name, then, beckons a viewer to set that individual within an everlasting memory in his or her own way, much as Virgil's words promise permanence to the specific "you" they address.

Virgil's interplay between different temporal perspectives also helps to develop the temporal nuances of the commemorative acts in Foundation Hall. Foundation Hall both enshrines earlier moments of commemoration and prompts new contemplations of how the past will be remembered. As Image 5 illustrates, the centerpiece of Foundation Hall is the Last Column, the final steel beam to be removed from Ground Zero. Covered with posters of the missing and graffiti signifying police and fire units that lost members in $9 / 11$, the column now stands in a location that reframes these prior memorials. Originally placed on the column to assist in the location of the missing or to mark the loss of the dead, the posters and graffiti now also function as a remembrance of the effort expended and loss suffered by those who survived the attacks. Just like Virgil's quotation stands both as a call to remember the dead and a commemoration of the act of memory itself, so does the Last Column; and, just as the Memorial Museum's use of the

11 Paumgarten 2011. 

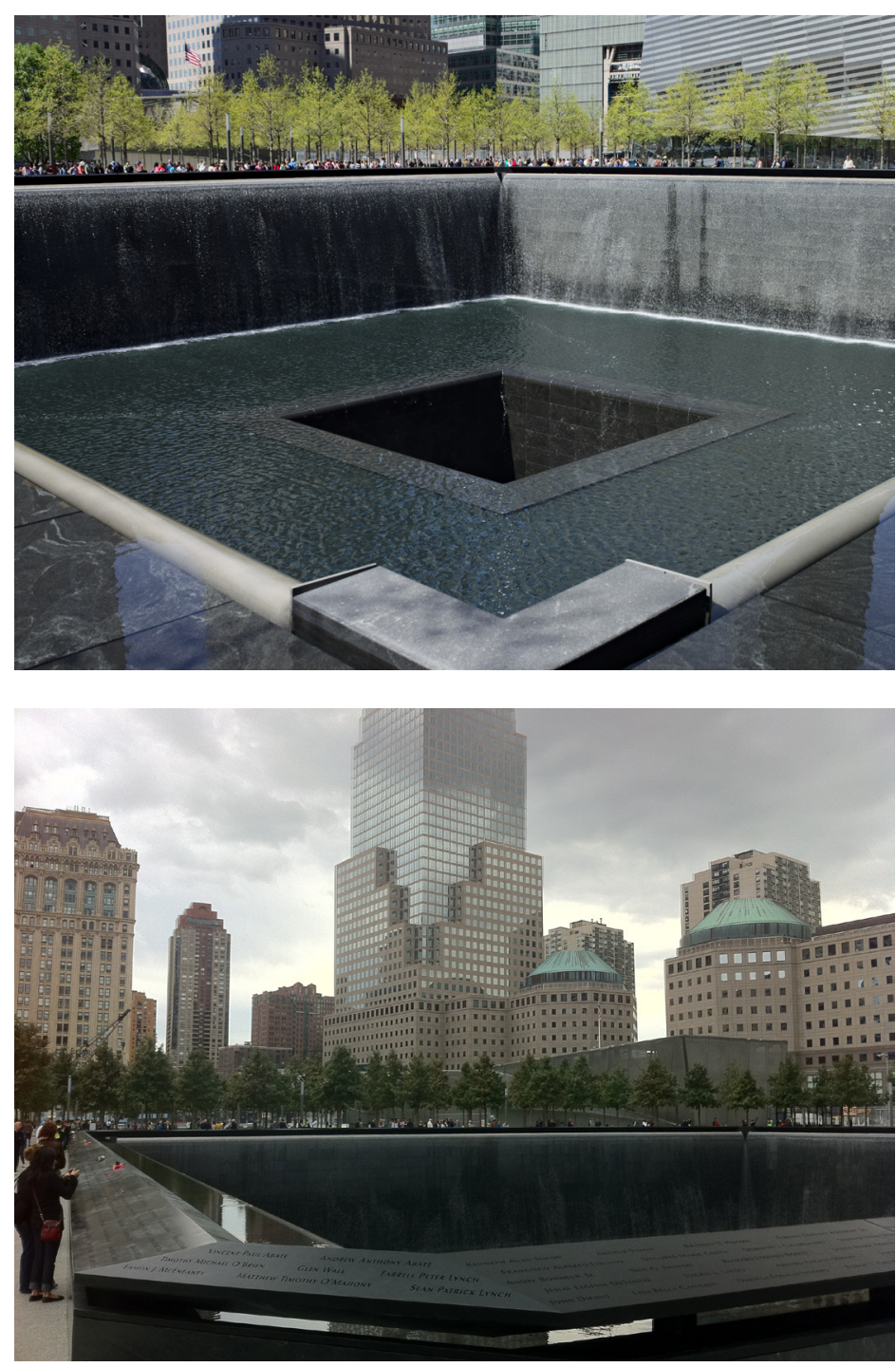

Fig. 3. Used under Creative Commons Attributions 2.0 Generic License. Picture taken by Nicolas Vollmer. https://commons.wikimedia.org/wiki/ File:M\%C3\%A9morial_du_World_Trade_Center (8856311127).jpg

Fig. 4. Used under Creative Commons AttributionShare Alike 2.0 Generic license. Picture taken by Kai Brinker. https://upload.wikimedia.org/wikipedia/ commons/7/73/North Tower Fountain National September_11_Memorial_\%26_Museum_\%28Sept._17 $\% 2$ C_2011\%29_\%282\%29.jpg 
Virgil words prompts one to consider his or her own commemorative acts alongside the memorializing impact of this Roman author, so do the artifacts within Foundation Hall encourage the viewer to reflect on how these commemorative effects relate to the hopes of those who placed posters or graffiti on the Last Column. The impulse to commemorate is universal but the perception of each act of memory is unique.

In a like manner, the quotation's use in the Memorial Museum offers insight into aspects of the scenes related to Nisus and Euryalus' death. More specifically, the Memorial Museum's mixture of verbal and material artifacts illuminates the range of commemorations that follow the soldiers' deaths as well as the uncontrollable interpretive energy generated by Nisus' appropriation of a foe's helmet.

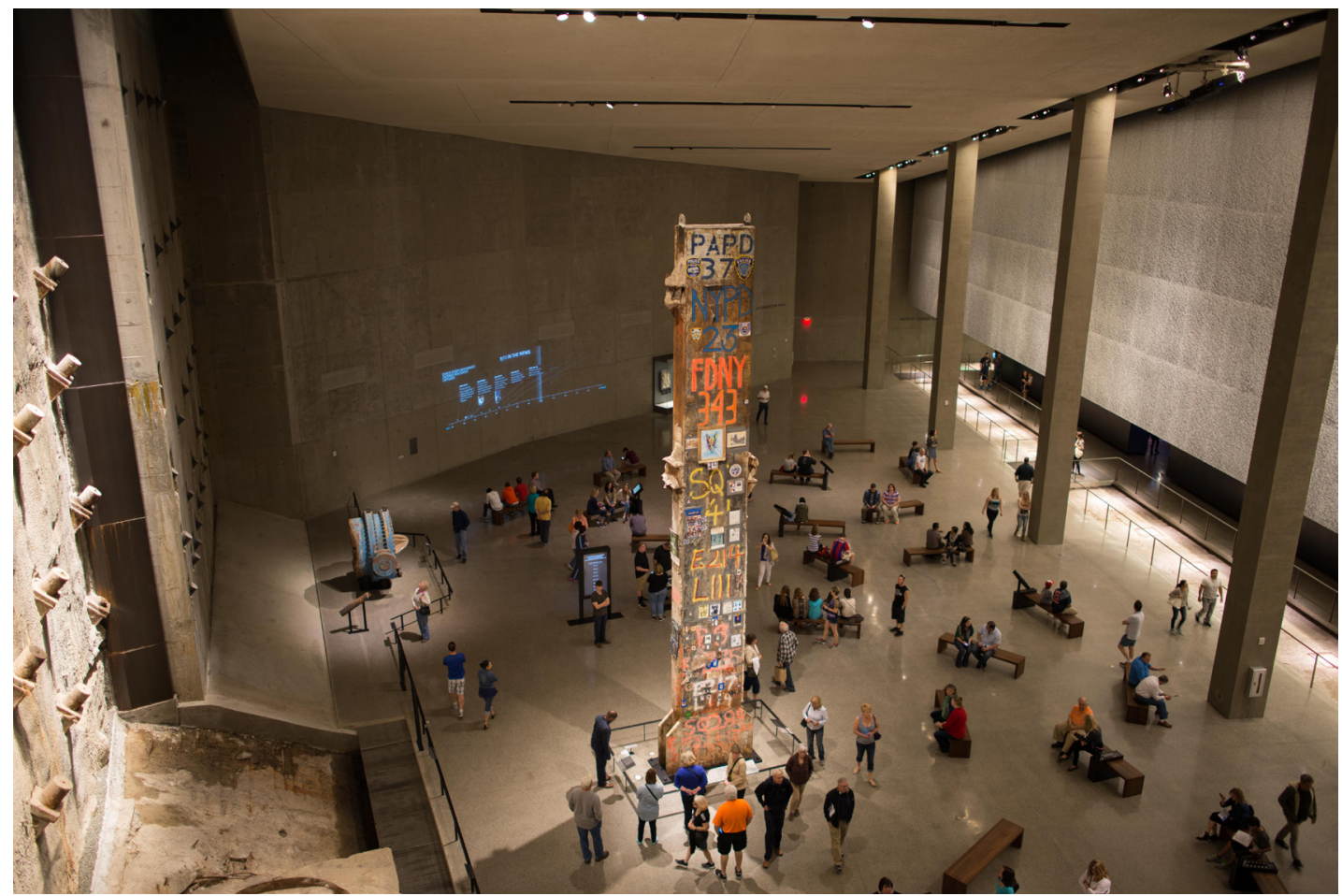

Fig. 5. Used under Creative Commons Attribution 4.0 International license. Picture taken by Fletcher. https://commons.wikimedia.org/wiki/File:September_11_Museum_Foundation_Hall.jpg 
The setting of Virgil's words within Spencer Finch's artwork evokes the range of possible memories that can relate to a single event. The sheets of paper in Finch's installation showcase the variability of memory, as each sheet represents an attempt to remember the same sky. Their range illustrates the challenges involved in attempting to establish a standardized commemoration of the past, even as the verse they encircle promises a permanent memory from the cultural institution. Termed an "oikotype," a standardized commemoration of the past is created by a community's actions regarding which version of the past "is acceptable and which is not." 2 The variability within Finch's painting emphasizes the different nature of the various reactions to Nisus and Euryalus' deaths. While the narrator's apostrophe focuses on their good fortune to die and be commemorated together, Euryalus' mother reacts in a much different manner. Seeing her son's head paraded on a spike outside the walls of the Trojans' camp, she cries out in anguish and laments her inability to properly bury her son. The brief rhetorical question which opens her speech encapsulates the difficulties she faces: "Is this you I see, Euryalus?" (hunc ego te, Euryale, aspicio?, Virgil, Aeneid 9.481). Denied the opportunity to commemorate him in the way she wishes, her question shows her inability to recognize and therefore control her son's identity, a commemorative abyss starkly opposed to the narrator's certainty of his own commemoration's everlasting nature. No oikotype is formed by the competing commemorations of Virgil and Euryalus' mother; rather they stand in discord with one another. Just as Finch's artwork illustrates how people can have different memories of the color of a sky on a single morning, it also emphasizes the irreconcilable memories of Nisus and Euryalus offered by the Aeneid. Indeed, while Virgil's quotation in Memorial Hall promises a standardized memory, the Aeneid does not.

The Memorial Museum's presentation of material commemorations also sheds light on the shifting meaning of material acts of appropriation in the Aeneid. As mentioned earlier, the enemy spots Euryalus when the moon glints off a helmet he stripped from a dead foe. Virgil's narrative underlines how Euryalus is undone by his commemorative efforts: "The helmet betrayed forgetful Euryalus in the barely luminous shade of night and reflected the light back from the rays of the moon" (galea Euryalum sublustri noctis in umbra / prodidit immemorem radiisque aduersa refulsit, Virgil, Aeneid 9.373-4). Through its presentation of material artifacts in Foundation Hall, the Memorial Museum illustrates how a material commemoration can prompt several different reactions, even moving beyond the meaning presumably intended by the one who fashions the commemoration. A poster originally designed to find a lost loved one, for instance, now exists as a marker that reminds the viewer of the dedication of those who searched. The helmet of Euryalus' enemy, seized by the Trojan to commemorate his martial

$12 \quad$ Fentress and Wickham 1992, 74. 
prowess, later marks his status as an enemy to the Latins and, after that, when the Latins take it back as a spoil of their own, it reminds them of the effort they expended to retrieve it.

\section{Coda: Roman Reappropriation}

As we reach this article's conclusion, I hope to have shown how the quotation in the Memorial Museum exemplifies the tension between the allure of antiquity and the impossibility of controlling its meaning, as Virgil's promise of eternal remembrance occasions larger concerns about time and audience that leave the signification of its words unstable. An acknowledged quotation placed in the most significant American memorial of the twenty-first century, this vow attempts to leverage the somber gravity of Virgil's canonical status, only to draw attention to the instability of its meaning in this new context. As questions arise about who is called to remember and who will be remembered, this verse destabilizes its authentication of the present. At the same time, though, this article has also explored how the engagement between this quotation in Memorial Hall and its context in the Aeneid adds complexity to the commemorative acts of both cultural institutions. A consideration of the modern museum in light of Book 9 of the Aeneid illuminates how its commemorations of 9/11 move between the unique and the universal, just as the words from Virgil's apostrophe promise that the remembrance of a unique individual may extend forever. From a different perspective, the backdrop of the Memorial Museum reveals the range of commemorative efforts associated with Euryalus in the Aeneid, efforts which fail to cohere in a single narrative and instead show how a commemoration depends on time, audience, and location.

In this coda, I consider the remarkable appearance of this same Virgilian quotation in a 2016 exhibit at the Capitoline Museum in Rome. Titled "Campidoglio: Mito, Memoria, Archeologia" ("Capitoline: Myth, Memory, Archeology"), this exhibit explores the history of the Capitoline and its representations from antiquity to the present. A room about half way through the exhibition focuses on Mussolini's transformation of the Capitoline from a place populated by residences and businesses to an archeological monument, and a series of photographs document the demolition of hundreds of the hill's buildings. Two opposing walls display quotations above these photographs. On one, seen in Image 6, is the statement "No day shall erase you from the memory of time," accompanied by an Italian translation and the attribution "New York, National September 11 Memorial and Museum." On the opposite wall, as seen in Image 7, stand lines 447-449 of Book 9 of the Aeneid, in both Latin and Italian and accompanied by precise attributions. These opposing quotations open a dialogue with one 
another and with their immediate context that in turn raises further questions about appropriation and commemoration in both the Memorial Museum and the Aeneid.

In their interaction, these quotations appropriate the commemorative power of the Memorial Museum's use of Virgil while also reclaiming these words for their "proper" Roman context. Without even a mention of Virgil, the Capitoline Museum's quotation from the Memorial Museum presents this other cultural institution as the words' author. Looked at on its own, this wall associates the earlytwentieth century destruction of buildings on the Capitoline Hill with the destruction of the World Trade Center in 2001, and this raises the possibility that the viewer should figure the early-twentieth demolition of the Capitoline's buildings as an attack on Italian values, life, and culture, albeit one carried out by the country's leaders. At the same time, it posits a link between Rome and New York City, two magnificent cities that have suffered destruction, yet survived. Moreover, while the "you" in the Memorial Museum must address the victims of 9/11, the "you" in the Capitoline Museum may invoke the buildings that were demolished, their inhabitants, the hill itself, or some combination thereof. In any case, it links their destruction with the victims of 9/11, and, in so doing, promises that they will be remembered with the same gravity and dedication as those who lost their lives in the 2001 attack.

The opposing wall resituates this selection from the Memorial Museum. Emblazoned in Italian and Latin, this quotation offers the original context for the opposite wall's words from the Memorial Museum and, in doing so, asserts the Virgilian authorship of this verse and reclaims it for Rome. As compared with the quotation of Virgil in the Memorial Museum, this selection in the Capitoline Museum is distinguished by its specific attribution of its source and its inclusion of a greater amount of its original context. As can be seen in comparison with the four-verse apostrophe in the Aeneid, the quotation in the Capitoline Museum includes three of the apostrophe's four verses, here printed in bold:

Fortunati ambo! si quid mea carmina possunt, nulla dies umquam memori vos eximet aevo, dum domus Aeneae Capitoli immobile saxum accolet imperiumque pater Romanus habebit.

-Virgil, Aeneid 9.446-449

Fortunate pair! If my songs have any power, no day shall erase you from the memory of time, not while Aeneas' house stands on the Capitoline's immovable rock and the Roman father holds sway. 
No day shall erase you from the memory of time.

Mai nessun giorno vi sottrarrà alla memoria del tempo.

New York, National September 11 Memorial and Museum.

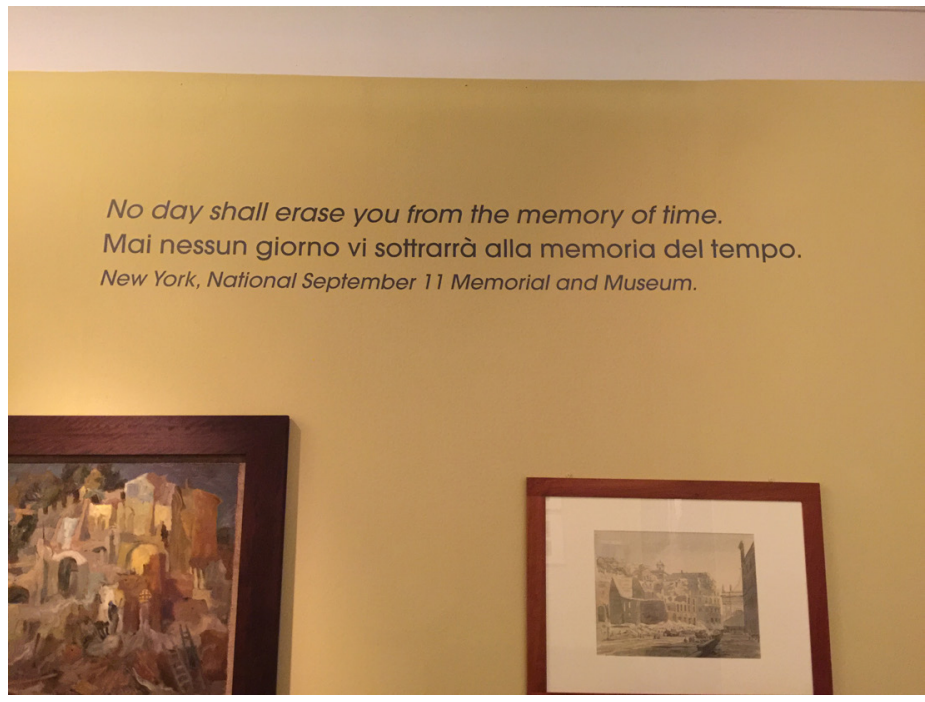

Fig. 6. Photo of room in "Capitoline: Myth, Memory, Archeology" exhibition in the Capitoline Museum. Picture taken by author.

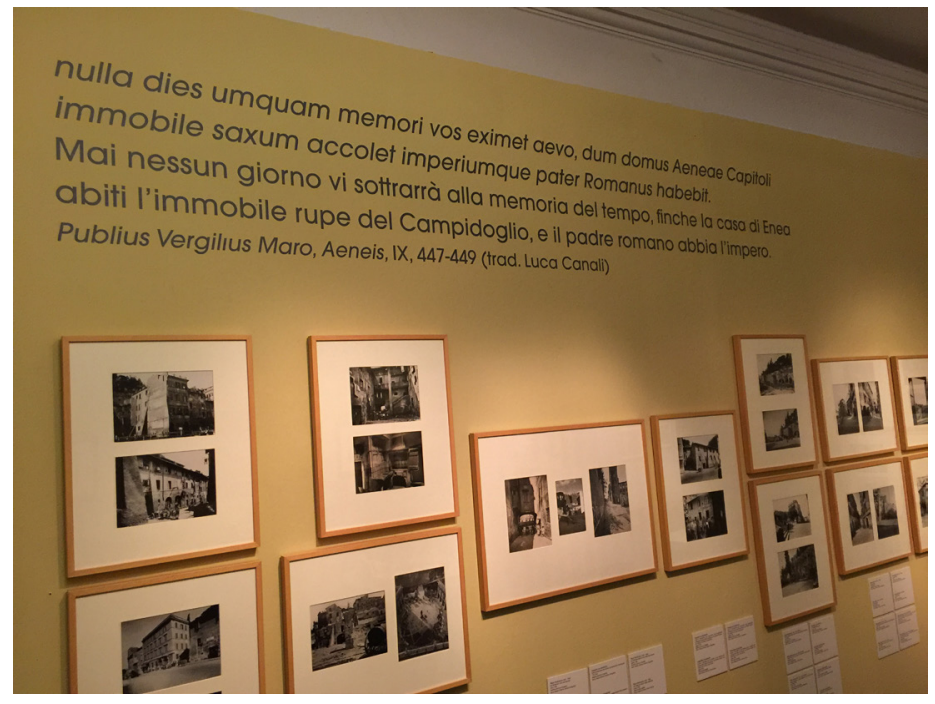

Fig. 7. Photo of room in "Capitoline: Myth, Memory, Archeology" exhibition in Capitoline Museum. Picture taken by author. 
While the Capitoline Museum includes more of the Virgilian context than the Memorial Museum, it still excises line 446, a decision which distances this quotation from the specific figures of Nisus and Euryalus and excludes any specific mention of Virgil's song. The additional verses that are included, namely lines 448 and 499, meanwhile, focus on specific Roman locations. Thus, the quotation emphasizes place instead of people, a fitting shift given that this particular room focuses on the destruction of buildings on the Capitoline Hill. Lastly, the inclusion of the Latin original and the specific attribution of this quotation to Virgil recall ancient Rome and thereby testify to the longevity of the Capitoline Hill in history and memory. In doing so, they also bolster the claim, implied by the quotation, that this exhibit promises to preserve the memory of the hill's earlier incarnations.

A specific passage in the Aeneid comes to mind in the context of these attempts by the Memorial Museum and the Capitoline Museum to claim this quotation, particularly given that both modern institutions use Virgil's words to commemorate urban destruction. In the epic's eighth book, Aeneas travels to Pallanteum to seek an alliance with Evander. As Aeneas walks around the city, his host describes the ruins they see before them:

haec duo praeterea disiectis oppida muris, reliquias veterumque vides monimenta virorum. hanc Ianus pater, hanc Saturnus condidit arcem; Ianiculum huic, illi fuerat Saturnia nomen.

-Virgil, Aeneid 8.335-358

Furthermore, you see these two cities with their walls thrown down, the remains and monuments of ancient men. This citadel founded by Janus, that by Saturn; this one is called the Janiculum, that one was called Saturnia.

To their original Roman reader, these lines would offer a dizzying confrontation of temporal perspectives. As Aeneas visits Pallanteum, the site where his descendants will one day found Rome, he sees the records of other civilizations which once occupied that very same location but have now fallen into destruction. Moreover, from their perspective, Virgil's readers may overlay their presentday Rome on top of these ruins, a new city that both succeeds and memorializes all those which came before. In this Virgilian vision, each city that arises is destroyed and, in its destruction, becomes a monument of itself and its inhabitants. 
It is a haunting portrait, one that displays how the remnants of the past become monuments for the future. The National September 11 Memorial Museum and the Capitoline Museum both use a line from Virgil's apostrophe for Nisus and Euryalus to commemorate acts of destruction suffered by their own civilizations. From this perspective, the destruction of civilizations and their subsequent commemorations in their ruins at Pallanteum portends that cities gain eternal memory only through their destruction. If we look back to this article's earlier discussion of Jonathan Culler's claim of how apostrophe moves the addressee into a timeless present, it is worthwhile to explore what such a commemorative apostrophe communicates about its speakers. Émile Benveniste (224-225) argues that the address of another in language creates "consciousness of self ... by contrast" and that "this polarity of persons is the fundamental condition in language" where neither "I" nor "you" "can be conceived of without the other." This quotation of a Virgilian apostrophe, then, creates both its own speaker and its own addressee. Not only do those people who died and those cities which were destroyed gain their presence and their commemoration through their destruction, but the individuals who memorialize them earn their own status as a subject through their commemorative efforts. This Virgilian apostrophe, which originates as an address to Nisus and Euryalus but now memorializes the victims of twentiethand twenty-first- century disasters, testifies to the existence of the individuals who commemorate, even as, in light of Virgil's magnificent description of the ruins that pre-date Rome, it hints that all civilizations gain their identity by commemorating the past and, more forebodingly, that all civilizations will one day be the subject of such commemoration themselves. 


\section{Works Cited}

ALEXANDER, Caroline. "Out of Context." The New York Times, 6 April 2011, p. A27.

BARTON, Edmund M. "Report of the Librarian." Proceedings of the American

Antiquarian Society, vol. 8, no. 2, 1893, pp. 347-362.

BENVENISTE, Émile. "Subjectivity in Language." Problems in General

Linguistics. Translated by Mary Elizabeth Meek, Coral Gables, FL: University of Miami Press, 1971, pp. 223-230.

CULLER, Jonathan. "Apostrophe.” Diacritics, vol. 7, no. 4, 1977, pp. 59-69.

DUNLAP, David. “A Memorial Inscription's Grim Origins.” The New York Times, 2 April 2014, p. A20.

"Scholarly Perspectives on the Inscription at the 9/11 Memorial Museum." The New York Times, 2 April 2014, www.nyti.ms/2jEuOVE.

ERASMO, Mario. Death: Antiquity and Its Legacy. New York: Oxford University Press, 2014.

FENTRESS, James and Chris Wickham. Social Memory: New Perspectives on the Past. Oxford: Blackwell, 1992. KENNEDY, Randy. "The Searing Blues of the 9/11 Sky: Spencer Finch

Turns to the Heavens to Honor the Dead." The New York Times, 15 May 2014, p. C1.

KNOLES, Tom. "Background on the AAS Diploma." Unpublished, Worcester: The American Antiquarian Society, 2015, 3 pages.

LIN, Maya. "Making the Memorial." The New York Review of Books, 2 Aug. 2000, www.nybooks.com/ articles/2000/11/02/making-the-memorial/. Accessed 8 February 2017.

MCKEOWN, J. C. "The 9/11 Memorial and the Aeneid: Misappropriation or Sincere Sentiment?" OUPblog, 2 May 2014, blog.oup.com/2014/05/911-memorial-and-aeneid/. Accessed August 22, 2016.

MYNORS, Roger A. B. P. Vergili Maronis Opera. Oxford: Clarendon Press, 1969.

PAUMGARTEN, Nick. "The Names." The New Yorker, 16 May 2011, pp. 38-40.

VERNANT, Jean-Pierre. "La Belle Mort et le Cadavre Outragé." La Mort, les Morts dans les Sociétés Anciennes, Gherardo Gnioli and Jean-Pierre Vernant eds., Cambridge: Cambridge University Press; Paris: Editions de la Maison des Sciences de l'Homme, 1982, pp. 45-76. 


\section{List OF ILLUSTRATIONS}

Fig. 1. Memorial Hall, National September 11 Memorial \& Museum at the World Trade Center Foundation, Inc. Photograph by Jin Lee. http://www.911memorial.org/sites/all/files/blog/images/memhall.JPG

Fig. 2. Membership Certificate of American Antiquarian Society. Courtesy American Antiquarian Society.

Fig. 3. Used under Creative Commons Attributions 2.0 Generic License. Picture taken by Nicolas Vollmer. https://commons.wikimedia.org/wiki/File:M\%C3\%A9morial_du_World_Trade_Center_(8856311127).jpg

Fig. 4. Used under Creative Commons Attribution-Share Alike ${ }^{-} .0^{-}$Generic license. Picture taken by Kai Brinker. https://upload.wikimedia.org/wikipedia/commons/7/73/North_Tower_Fountain_National_ September_11_Memorial_\%26_Museum_\%28Sept._17\%2C_2011\%29_\%282\%29.jpg

Fig. 5. Used under Creative Commons Attribution 4.0 International license. Picture taken by Fletcher. https://commons.wikimedia.org/wiki/File:September_11_Museum_Foundation_Hall.jpg

Fig. 6. Photo of room in "Capitoline: Myth, Memory, Archeology" exhibition in the Capitoline Museum. Picture taken by author.

Fig. 7. Photo of room in "Capitoline: Myth, Memory, Archeology" exhibition in Capitoline Museum. Picture taken by author. 